Press, appeared this week. All new journals of this kind are necessarily precarious ventures, but there are good hopes that this one will fulfil the need it has been produced to meet. It is taking the place of the Transactions of the Club, which have been published now for more than fifty years. It will contain the more important lectures given from time to time to the Club, discuss problems connected with study and research in science and medicine at Oxford and review the work of the different scientific departments. The opening number contains the Robert Boyle lecture by Sir Edward Mellanby on methods of discovery in the fight against disease, an article by Prof. F. Paneth on atomic transmutation, an account of recent investigations on the structure of proteins by D. Parker Riley and an article discussing and criticizing medical curricula by one of the medical tutors. Some of the articles are illus. trated. There are also editorial and other notes and a few book reviews. Altogether this is a lively first number that should make a wide appeal to the student of science interested in other sciences besides his own and in the problems that their impact on the world and the university has produced.

\section{Gardeners of Essex}

THE presidential address of Dr. John Ramsbottom to the Essex Field Club provided an opportunity to present much historical gardening knowledge in a pleasant, intimate form ("Old Essex Gardeners and their Gardens", Essex Naturalist, 26, 65-103 ; 1938). Yucca first flowered in England during the year 1604, in the garden of William Coy at Stubbers, North Okington. This same garden also enjoys the distinction that it was the source whence the ivyleaved toadflax, Linaria cymbalaria, first spread to become apparently native upon walls throughout England. It would be difficult to over-estimate the valuable work of another Essex gardener, Lord Petre, who stimulated the collection of many foreign plants which have become accepted beautifiers of British gardens. Richard Warner of Woodford introduced the genus Gardenia to English horticulture in 1754, and Dr. John Fothergill, 1712-80, had an influence similar to that of Lord Petre. He stimulated numerous useful projects, and himself cultivated many new and curious plants. No geographical limits were set by these Essex plant collectors, but they appear to have been especially responsible for the introduction of North American species to the gardens of Europe.

\section{National Planning}

THe Town Planning Institute has issued a report of the National Survey and National Planning Committee (price 1s.). The report stresses several matters of importance, and points out that in England and Wales (for Scotland is not included) about three quarters of the local authorities have applied the various Acts to about two thirds of the total land area. The process of planning, however, appears to be slow and essentially local in outlook. The Committee believes that national planning is required to supplement and reinforce local and regional planning. There is no national policy or guidance in the preserva. tion of land for agriculture and for the reservation of national parks and other large open spaces. Further, in problems of transport, such as roadways and airports, a national, rather than a regional, outlook is necessary. The report contains a strong plea for a new department of Government which should take the form of a National Planning Commission. Its functions would be, first, the completion of a national survey, and secondly, advice and guidance to other Government departments and local authorities. Thus it would be possible to formulate and execute a national policy in the utilization of land.

\section{Earthquake in the East Indies}

The U.S. Coast and Geodetic Survey, Washington, D.C., has announced the occurrence of an earthquake on October 10d. 20h. $48 \mathrm{~m}$. G.C.T. with provisional epicentre lat. $1^{\circ} \mathrm{N}$., long. $125^{\circ} \mathrm{E}$. The epicentre was determined from instrumental data obtained at twelve United States seismological observatories. The epicentre is to the west of the Molucca Passage and the nearest town of any size is Menada in the north of Celebes. No damage has so far been reported from here. According to Dr. $\mathrm{S}$. W. Visser and his colleagues of the seismological observatory at Batavia, small earthquakes are quite frequent near this spot. World-shaking earthquakes are somewhat infrequent, however, and the last ones were the swarm of July 10-12, 1926, epicentre lat. $1^{\circ} \mathrm{N}$., long. $126^{\circ} \mathrm{E}$. It is possible that the earthquake on July 10,1926 , was multiple, as the $P$ residuals appear to show groupings which are confirmed by the $S$ residuals.

\section{Traffic in Women and Children}

ThE League of Nations Committee for the Sup. pression of Traffic in Women and Children recently proved by investigation that there is a connexion between licensed houses of prostitution and traffic in women. The League, therefore, sought information from many Governments and voluntary associations respecting the early lives of women who afterwards became prostitutes, and has issued an analysis of this information, with comments, in a report recently issued ("Prostitutes : their Early Lives". Geneva, 1938. London: Allen and Unwin. 3s.). Some 60 per cent of the women were considered to be below normal in intelligence. Poverty and destitu. tion, early seduction, and the desire for an easy life seem to be the main causes responsible for women adopting this kind of life.

\section{Monkeys as Botanical Collectors}

The Kew Bulletin No. 7, 1938, quotes from the annual report of the Director of Gardens, Straits Settlements, an account given by the acting director, Mr. E. J. H. Corner, of the use made of berols monkeys (Macacus nemestrina) to collect specimens from tall trees. Two young beroks are at present employed; they understand twelve words of Kelantanese and can thus be instructed to pick specific twigs and drop them to the ground. Mr. Corner states, "A berok upon the shoulder can be likened, in effect, to a falcon on the wrist; and its employment is recommended both to amateurs for its charm and cheap- 
ness and to keepers of Reserves where it is desirable to collect specimens repeatedly from the same trees without damage to them."

\section{Science Masters' Association}

THE thirty-ninth annual meeting of the Science Masters' Association will be held in the University of Cambridge on January 3-6, 1939. On January 3, Prof. J. Gray will deliver his presidential address on "The Role of Science in Education". The following lectures have also been arranged: Prof. E. V. Appleton: "The Upper Atmosphere"; G. C. L. Bertram, "Animals of the Antarctic"; Prof. R. G. W. Norrish, "Experiments in Photochemistry"; Prof. W. L. Bragg, "X-Ray Optics"; Prof. O. T. Jones, "The Making of a Geological Map"; Dr. H. B. Cott, "Visual Concealment in Nature and in War" ; N. E. Odell, "Everest, 1938". On January 6, a discussion will be held on "Films in the Science Classroom". Further information can be obtained from Mr. W. Ashhurst, The Grammar School, Stretford, Lancs.

\section{The Night Sky in December}

THE night lasts for $16 \frac{1}{4}$ hours in the latitude of London at the time of the winter solstice on December 22. The moon is full on December 7 and new on December 21. The moon's altitude when southing at Greenwich on December $8^{\mathrm{d}} 0^{\mathrm{h}} 27^{\mathrm{m}}$ U.T. is $583^{\circ}$. No star brighter than mag. $5 \frac{1}{2}$ is occulted during the month. Conjunctions between the moon and planets occur as follows : December $3^{\mathrm{d}} 2^{\mathrm{h}}$, Saturn : $17^{\mathrm{d}} 7^{\mathrm{h}}$, Mars : $18^{\mathrm{d}} 16^{\mathrm{h}}$, Venus : $20^{\mathrm{d}} 14^{\mathrm{h}}$, Mercury : $27^{\mathrm{d}} 0^{\mathrm{h}}$, Jupiter : $30^{d} 11^{\mathrm{h}}$, Saturn. On December 5 there is a fairly close approach between the moon and Uranus, actually resulting in an occultation of the latter as seen from parts of Asja and North America. Jupiter and Saturn are both evening stars. At about $184^{\mathrm{h}}$ on the following dates, the four inner satellites are grouped fairly closely to Jupiter, being easily seen in a pair of binoculars: December $1^{\mathrm{d}}$ (Satellite $I$ occulted), $2^{\mathrm{d}}, 10^{\mathrm{d}}$ (Satellite IV occulted) $17^{\mathrm{d}}, 18^{\mathrm{d}}, 19^{\mathrm{d}}$, $25^{d}$ to $28^{d}$. Mercury, Venus and Mars are all morning stars. In mid-December, Venus rises about $5^{\text {h }}$; it is at its greatest brilliancy (mag. -4.4) on December 26. The variable star, Algol, is well placed for observation during the month. The approximate times of primary minima accessible to observation are on December $2^{\mathrm{d}} 4 \cdot 5^{\mathrm{h}}, 5^{\mathrm{d}} 1 \cdot 3^{\mathrm{h}}, 7^{\mathrm{d}} 22 \cdot 1^{\mathrm{h}}$, $10^{\mathrm{d}} 19 \cdot 0^{\mathrm{h}}, 25^{\mathrm{d}} 3 \cdot 1^{\mathrm{h}}, 27^{\mathrm{d}} 23 \cdot 9^{\mathrm{h}}, 30^{\mathrm{d}} 20^{\circ} \cdot 7^{\mathrm{h}}$. On or about December 11 the Geminid meteors are at their maximum. In the middle of the month at midnight, there is a fine array of bright stars on the southern meridian.

\section{Announcements}

Prof. ANDrew Cowper Lawson, emeritus professor of geology and mineralogy at the University of California, has been awarded the Penrose Medal, highest honour of the Geological Society of America, "for eminent research in pure geology, and outstanding original contributions and achievements which mark a decided advance in the science of geology".

Prof. James Kendall, professor of chemistry in the University of Edinburgh, will deliver the Christ- mas Lectures "adapted to a juvenile auditory" at the Royal Institution on January 3, 5, 7 and 10. The subject of the lectures will be "Young Chemists and Great Discoveries".

Mr. K. de B. Codrington, keeper of the Indian Section of the Victoria and Albert Museum, has been appointed to give the Charles Phelps Taft Memorial Lecture at the University of Cincinnati in January. Mr. Codrington has been attached to University College, London, for many years as honorary lecturer in Indian art, and is chairman of the Indian Research Committee of the Royal Anthropological Institute. He held the chair of archæology at the University of Cincinnati in 1925-26. His present invitation to the United States is an indication of the increasing interest there in India, and especially Indian art. Mr. Codrington intends to investigate the educational activities of various museums in the United States during his visit.

The Nobel Peace Prize for 1938 has been awarded to the Nansen Office for Refugees in Geneva. The Nansen Office ceases its activity at the end of this year, and its duties will be continued in London by the newly founded International Commission for Refugees. The Prize will automatically be transferred to the new Commission in London, the director of which is Sir Herbert Emerson.

The Geophysical Discussion at the Royal Astronomical Society on "The Night Sky and Aurora", arranged for January 27, has been postponed to May 19. The discussion arranged for May 26 is cancelled. On March 24, 1939, Dr. E. C. Bullard will open a discussion on "Recent Geophysical Investigations at Sea".

Messrs. Francis Edwards, Ltd., 33 Marylebone High Street, W.1, have issued a catalogue (No. 630, 1938) containing many rare examples of books relating to the sea, atlases, autograph letters, log books, etc. The gems of the collection are, perhaps, a fine first edition of Sir William Alexander's "An Encouragement to Colonies" (1624), "Hakluytus Posthumus" of Purchas (1624-26), "The Principal Navigations" of Richard Hakluyt (1598-1600) and an atlas, the "Strassburg Ptolemy" (1513). There is also a long series of works, with many rarities, dealing with the Bounty mutiny and Captain Cook's voyages. Among scientific works listed we notice copies of the "Challenger Report", Sir J. D. Hooker's "Botany of the Antarctic Voyage" of the Erebus and Terror, the "Botany and Zoology of the Voyage of H.M.S. 'Sulphur' ", Darwin's "Surveying Voyages of H.M.S.'s 'Adventure' and 'Beagle' ", and a complete set of the Journal of the Polynesian Society.

In the short notice of J. Halcro-Johnson's "Reverse Notation" on p. 775 of NATURE of October 29, the reviewer, in quoting examples of the abundance of negative digits, inadvertently omitted the word 'minus' before $\log 6 \cdot \mathbf{3} \overline{3} 5$. According to the reverse notation, $\log 6 \cdot \overline{3} \overline{3} 5=1 \cdot \overline{3} \mathbf{2} 04$, but in converting subtraction into addition, minus $\log 6 \cdot \mathbf{3} \overline{3} 5=\overline{\mathbf{l}} \cdot \mathbf{3 2 0 \overline { 4 }}$ is used. 